\title{
Trædeild og skattegravning
}

Historien og samtiden i en sønderjysk fortællers sagn

\section{Af Martin Sejer Danielsen}

I artiklen analyseres eksempler på den folkloristiske genre sagn fortalt af den sønderiyske fortæller Christian C. Haugaard (1836-1920) i forhold til hans person og den tid, han levede i. Haugaard blev interviewet i Aabenraa i 1894 og 1902 af folkemindesamleren Evald Tang Kristensen (1843-1929), og særligt to sagn fremhæves. Det ene sagn er inspireret af en litterær kilde, og det peger på Haugaards forhold til øvrigheden i den daværende tyske provins. Det andet sagn viser noget om Haugaards holdning til den økonomiske vækst i landsdelen i forhold til hans egne bestræbelser på at få del i den forøgede velstand. ${ }^{1}$

\section{Indledning}

De tyske brødre Jacob (1785-1863) og Wilhelm Grimm (1786-1859), der er bedst kendt for deres udgivelser af eventyr, udgav i 1816-1818 to bind af Deutsche Sagen ('tyske sagn'). I indledningen til første bind definerede de genren sagn i sammenligning med eventyret: Eventyret, fandt de, er mere poetisk, mens sagnet er mere historisk. ${ }^{2}$ Med dette mente brødrene omtrent, at sagnet, modsat eventyret, bærer præg af at være en historisk fortælling, måske endda om noget (delvist) virkeligt forekommet. Denne grundopfattelse har op gennem tiden fået forskere til at lede efter en historisk kerne i sagnene ${ }^{3}$, og i Danmark redegjorde særligt historikeren Kristian Erslev (1852-1930) og folkemindeforskeren Axel Olrik (1864-1917) for, hvordan man kunne finde ind til et givet sagns historiske kerne - eller udelukke at en sådan kerne var at finde i sagnet. ${ }^{4}$

I dag er man i folkloristikken gået fra denne forståelse af sagnet. Norske Brynjulf Alver (1924-2009) viste i 1962, hvordan sagn ikke har sin værdi som kilde til de historiske begivenheder, der fremstilles i sagnet. Til det formål bliver fortællingen om hændelsen hurtigt skematiseret, som den går fra mund til mund, idet handlingerne i enslydende fortællinger blandes sammen. ${ }^{5}$ I sagn inddrages nemlig ofte motiver, som folkloristen genkender på tværs af tidsmæssige, geografiske og sågar generiske skel (altså de folkloristiske genrer eventyr, sagn, viser osv.). Men med sagnet ønsker fortælleren som udgangspunkt at fremstille 
noget troværdigt, og derfor tager hans sagn sig også ud som noget, der kunne være sandt, noget, der kunne være foregået engang i en mere eller mindre defineret fortid $i$ hans eget kendte landskab, og dette selv om hans fortællinger indeholder overnaturlige elementer.

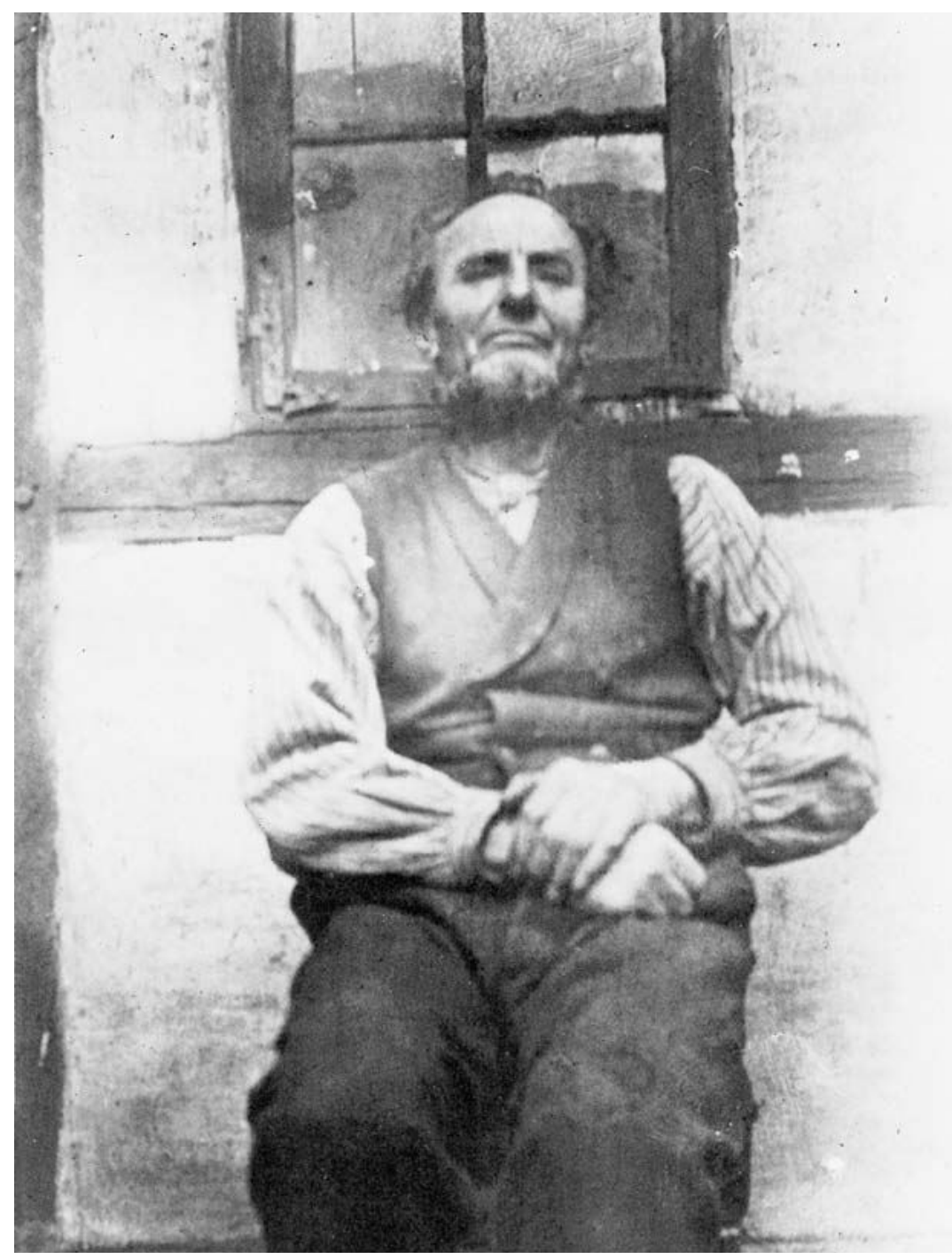

Figur 1: Christian C. Haugaard fotograferet i Aabenraa. Foto: Evald Tang Kristensen, 1905. Dansk Folkemindesamling, Det Kgl. Bibliotek (DFS bnr. 00104).
Sagnfortællerens retoriske strategier for at skabe troværdighed i sagnet er ligefrem blevet fremhævet som noget af det mest kendetegnende for genren. ${ }^{6}$ Troværdigheden opstår også, fordi handlingen i sagnet foregår i fortæller og tilhøreres eget, kendte landskab - oftest helt bogstaveligt, idet virkelige lokaliteter som gravhøje, byer, åer osv. udpeges i sagnet, typisk ved navns nævnelse.?

Som generiske træk kan også føjes, at sagnet typisk er relativt kortfattet (i sammenligning med eventyret) - ofte fremstilles kun én eller ganske få episoder - og i dagligdagen florerer sagn som del af almindelige samtaler. Hertil - og vigtigt for den teoretiske vinkel, jeg har til nærværende artikel - spejler sagnet den gruppe, der interesserer sig for det, og viser noget om den stillingtagen, fortælleren som medlem af samfundet har til forskellige små og store ideologiske spørgsmål i sin egen samtid. ${ }^{8}$ Derfor bør sagnet læses i nær relation til det menneske, der fortalte sagnet, og i den samtid, sagnet blev fortalt i, både den umiddelbare fortælleomstændighed og den politiske, sociale og økonomiske kontekst, som sagnfortælleren levede under. ${ }^{9}$

Ved at følge de teoretiske og metodiske grundlinjer i arbejdet med arkiveret folkloristisk materiale benyttet og udviklet blandt andet af Bengt Holbek (1933-1992), Timothy R. Tangherlini og mig selv ${ }^{10}$, vil jeg vise, hvordan en sønderjysk informant, Christian C. Haugaard (18361920), fortæller sagn, der skaber betydning og relevans for ham selv $i$ forhold til hans egen person og den tid, som han lever i. Ved at kombinere personalhistoriske informationer fra arkiverne, særligt folketællinger og kirkebøger, med viden om sagnfortællerens historiske virkelighed kan vi komme nærmere en forståelse af sagnets betydning set fra sagnfortællerens synspunkt.

\section{Christian C. Haugaard - en introduktion}

Christian Christensen Haugaard ${ }^{11}$ var blandt de mange informanter, som den danske folkemindesamler Evald Tang Kristensen (1843-1929) mødte i 1894 på en længere indsamlingsrejse syd for Kongeåen. Landsdelen, som vi i dag forstår som Sønderjylland, var i perioden 1864-1920 den nordlige del af den preussiske og senere tyske provins Slesvig, men Tang Kristensen opsøgte udelukkende dansksindede og -talende informanter hernede..$^{12}$

Tang Kristensen møder Haugaard i Aabenraa tre gange: Første gang er i 1894, anden gang i 1902 og sidste gang i $1905 .{ }^{13}$ Ved det sidste møde 
har Tang Kristensen fotograferet Haugaard ${ }^{14}$ (se figur 1), og sikkert ved samme anledning har Tang Kristensen udspurgt Haugaard om hans liv med henblik på at udarbejde følgende lille levnedsbeskrivelse:

Christian Christensen Haugaard er født d. 12te dec. 1838 i Nørre Hjarup, Øster Løgum Sogn. Han blev farversvend og bor endnu som sådan i Aabenraa, hvor han ejer sit eget lille hus og lever ugift. Besjælet af glødende fædrelandskærlighed har han måttet give [0: betale] bøder og er for resten et ret mærkeligt menneske, poetisk anlagt og tillige meget påholdende, fyr og flamme for hvad der netop griber ham og dog beregnende til det yderste. Sine historier har han fra egnen omkring hjemmet. Det var særlig moderen der fortalte, men også faderen[,] dennes broder og fasteren. ${ }^{15}$

Kirkebogen fra Øster Løgum Sogn afslører, at Tang Kristensen har fået galt fat $\mathrm{i}$ årstallet for Haugaards fødsel: Han er ganske rigtig født 12. december i Nørre Hjarup, Øster Løgum Sogn, men der er under året 1836, at vi finder Haugaards fødselsdag optegnet i forbindelse med hans dåb. ${ }^{16} \mathrm{I}$ folketællingen 1845 boede familien Haugaard på et kådnersted, og i kirkebogsnotatet om Haugaards konfirmation palmesøndag 1853 er faderen, Christian Haugaard (1795-1861), igen registreret som kådner..$^{17}$ I Hertugdømmet Slesvig, som vi jo befinder os i indtil 1867, svarer en kådners jordbesiddelser omtrent til en husmand i Kongeriget: Man har haft jord nok til en ko eller to, har nogenlunde kunnet leve af sit sted, men kådneren har ofte måttet supplere sin indkomst, eksempelvis med håndværk eller lønarbejde. ${ }^{18}$ I folketællingen 1845 er faderens erhverv netop angivet som daglønner. ${ }^{19}$

I folketællingen 1860 finder vi igen vores sagnfortæller Haugaard. Han var bosiddende i Aabenraa som udlært farversvend, og han boede hos farvermester Mads Jacob Festesen med familie. ${ }^{20}$ Familien Festesen ejede en klædefabrik i byen helt frem til 1905, hvor fabrikken ikke længere havde nogen ansatte. ${ }^{21} \mathrm{En}$ farver er nemlig en håndværker, der beskæftiger sig med farvning af tekstiler. Det er ikke utænkeligt, at Haugaard arbejdede på Festesens Klædefabrik og allerede var gået i lære hos Festesen i Aabenraa allerede kort tid efter sin konfirmation i 1853.

Fra Aabenraa er bevaret en række folketællinger foretaget i købstaden hvert femte år i perioden 1885-1910. Haugaard var i 1885 stadig bosiddende hos sin mester med adressen Ramsherred 28, men i 1890 er han flyttet væk fra sin mester til adressen Ramsherred 24. På denne

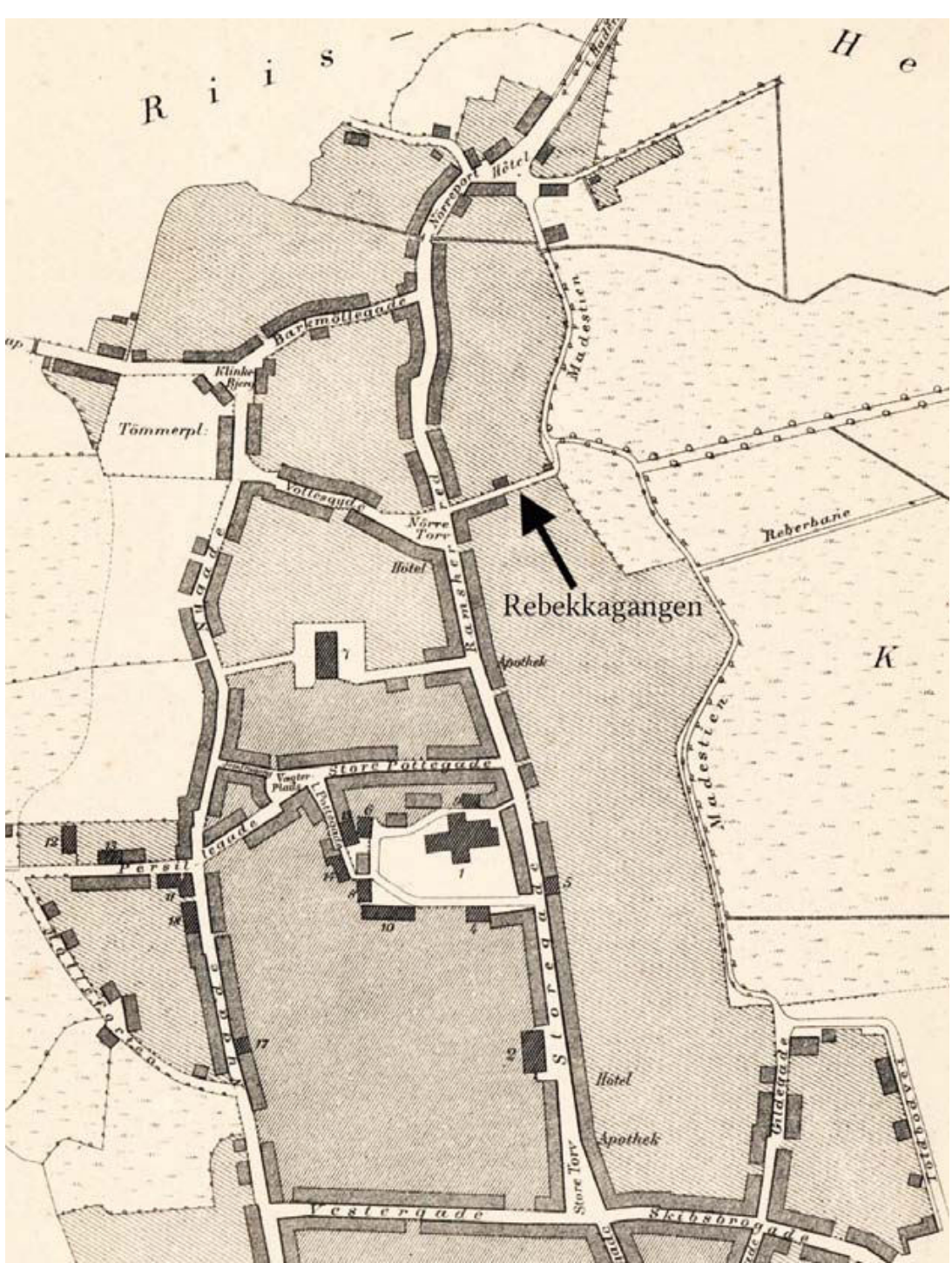

Figur 2: Udsnit af kort over Aabenraa i 1862. Den sorte pil peger på Rebakkagangen, hvor Haugaard boede som pensionist. Kort: W. Lumholtz, J.P. Trap og Emil Bærentzen, 1864. Foto: Det Kgl. Bibliotek.

adresse boede han frem til et tidspunkt mellem 1900 og 1905, for i folketællingen fra 1905 finder vi ham som pensionist i et hus med adressen Rebekkagang 1 (se figur 2 og 4). På denne adresse døde han i 1920.22 


\section{Haugaards repertoire af sagn - fra optegnelse til udgivelse}

For at komme så nær på den dag, hvor sagnfortællingen foregik, analyserer jeg sagnene som de læses i Evald Tang Kristensens feltnoter, de såkaldte Dagbøger, der i dag ligger arkiveret hos Dansk Folkemindesamling ved Det Kgl. Bibliotek i København. ${ }^{23}$ Tang Kristensen optegnede som nævnt sagn hos Haugaard i både 1894 og 1902. I feltnoterne står sagnene som udgangspunkt optegnet i den rækkefølge, som de har været fortalt i, om end Haugaards materiale står optegnet i flere opsplittede sektioner (fem sektioner i 1894, og to i 1902).

Alligevel kan vi ofte se koblingerne fra det ene sagn til det næste, hvilket er en naturlig konsekvens af den interviewsituation, som Tang Kristensens indsamlingspraksis medførte. Med andre ord fornemmer man gerne, hvorfor Haugaard kom i tanker om næste sagn, fordi vi kan se eksempelvis en tematisk kobling til forrige sagn. I Haugaards samlede sagnrepertoire får vi endvidere et overordnet indblik i de temaer, der optog ham. Ønsker vi således at forstå betydningen af et specifikt sagn, kan vi med fordel kigge på, hvad han i øvrigt har meddelt Tang Kristensen. Sagnfortællere har det nemlig med at kredse om de samme temaer. ${ }^{24}$

Når Tang Kristensen forberedte sagnene til udgivelse i sit storværk Danske sagn (1892-1901, ny række 1928-1939), omarbejdede han sagnene. Den mest indgribende omarbejdelse består faktisk i, at han udgav materialet typologisk og ikke kronologisk. Således er Haugaards sagn spredt ud i mange forskellige bind af begge rækker af Danske sagn efter Tang Kristensens personlige skøn om hvilken kategori, de bedst hørte under, ligesom enkelte sagn er udgivet $\mathrm{i}$ andre af Tang Kristensens udgivelser, og enkelte stykker vistnok aldrig er blevet trykt. Læser vi kun sagnene fra de trykte værker, er de føromtalte, ofte tydelige koblinger fra det ene sagn til det næste altså fuldstændigt udviskede.

I de enkelte trykte sagn har Tang Kristensen også foretaget små stilistiske ændringer, hvor han har flyttet rundt på sætninger, tilføjet ord og tilføjet tegnsætning - alt sammen mestendels for at give sagnet en mere læsevenlig struktur. Enhver nær analyse af sagnene bør derfor principielt udgå fra feltnoterne og ikke de trykte versioner, for i feltnoterne er vi tættere på den umiddelbare, mundtlige fortællestil, hvor vi fornemmer, hvordan sagnfortælleren eksempelvis indskyder bemærkninger og retter sig selv midt i sagnet.

Men da versionerne fra feltnoterne kan være lidt rodede at læse på grund af manglende tegnsætning, forkortelser af hyppigt forekommen- de ord (f.eks. hun, han og så), tilføjelser over linjen og lignende, vil jeg i denne artikel citere Tang Kristensens trykte version af sagnene. ${ }^{25}$

\section{Sagnet om 'Bråvrup træedeild'}

Haugaard døde den 17. februar 1920 - en dato både kirkebogen fra Aabenraa og personregisterføreren vidner $\mathrm{om}^{26}$ - og allerede dagen efter i den dansksindede Flensborg Avis annonceredes hans død med følgende lille nekrolog, hvor jeg her kun citerer de første to af tre afsnit:

C.C. Haugaard, en dansk patriot og særling, er død 83 år gammel. Få havde glædet sig til genforeningen som han, og da afstemningsdagen så endelig oprandt, overvældede glæden ham helt; han fik en hjertelammelse og kunne ikke afgive sin stemme. Den afdøde var kendt videnom; han beboede et lille hus ved Maden og førte en primitiv tilværelse. I sin lejlighed havde han et bibliotek af danske bøger, som han lånte ud. Han var kernedansk, og hele hans interesse optoges af danskhedens kamp imod fortyskningen. ${ }^{27}$

Nekrologen etablerer med det samme Haugaards dansk-patriotiske eftermæle, som han i eftertidens beskrivelser af ham er blevet særligt bemærket for. Ingeborg Refslund Thomsen (1891-1972) biograferede Haugaard i Sønderjydsk Maanedsskrift i juli 1940, og redaktør Carl Johan Bech (1906-1957) skrev i 1945 og 1956 om Haugaard som en af Aabenraas originaler. ${ }^{28}$ Haugaards død skulle altså, også ifølge disse biografier, ligefrem være forårsaget af udsigten til afstemningen den 10. februar 1920; den afstemning, hvor det blev afgjort, at den nordlige del af Slesvig skulle føres tilbage til Danmark. ${ }^{29}$ I eftertiden bliver denne detalje om hans dødsårsag gentaget flere gange, og datoen for hans død i de forskellige benævnelser af ham flytter fra at være op til otte dage efter afstemningen til at være før eller på selve afstemningsdagen. ${ }^{30}$

Haugaard kunne, som de fleste i hans samtid, sagtens læse, og hans lille lejebibliotek vidner om, at han havde adgang til bøger. Egentlig er det uklart, om biblioteket var del af de privatdrevne danske bogsamlinger, der organiseredes af Sprogforeningen fra 1880'erne ${ }^{31}$, men at Haugaard var en god ven af Sprogforeningens formand Mathias Andresen (1858-1916) $)^{32}$, taler jo for, at Haugaard i hvert fald blev inspireret af dette projekt. Ifølge Tang Kristensen bestod Haugaards i øvrigt velbesøgte 
bibliotek mest af danske romaner, og Bech nævner, at Haugaards bogsamling bestod af forskelligt sammenskrabet litteratur, der ikke var af den lødigste art. ${ }^{33}$

Haugaards dansksindede væsen kommer faktisk sjældent direkte til udtryk i hans repertoire af sagn. I flere sagn fornemmer vi i stedet Haugaards hverdagslige forhold til øvrigheden, herunder særligt politi, militær og retssystem. Lad os kigge på følgende eksempel fra Haugaards repertoire:

Hvert efterår, når rugen er inde, ser man altid tre lys brænde ved Rugbjerg, og de vimper altid op og ned. Spørger man, hvad det er, så svarer folk: »Ja, det er Bråvrup trædeild. « De er fremkomne på følgende måde. En mand solgte sin løkke til en anden mand og tog betaling for den. Men samme nat døde manden, og der var ingen skrifter på handelen. Det kom til proces, og sælgeren og hans kone og søn skulle sværge på, at løkken var deres, og at de ingen betaling havde fået for den. Men så tog han jord af sin egen have i støvlerne og gik til tinget med. Han tabte dog sålerne, inden han kom der, men så truede konen ham til, at han skulle sværge alligevel, som han da også gjorde. Efter den tid kom der hver nat en røst for hans vinduer, som sagde: „Giv løkken tilbage, så kan både du og din kone og søn blive frelst.« Imidlertid kom præsten om til dem og sagde: "Endnu er det tid at få det rettet. Her lægger jeg en lås på bordet, og den vil give sig til at kneppe [o: 'give en knækkende, skarp lyd'34]. Inden den får kneppet 12 gange, er det endnu tid at give løkken tilbage, men derefter er det for sent.« Alle tre nægtede hårdnakket og ville ikke give en fodsbred tilbage, de ville hellere undvære Guds rige [end] blive arme. Præsten blev ved at være der, og da nu låsen havde slået 9 slag, sagde præsten: »Betænk jer, betænk jer.« Der var omtrent et minut mellem hvert slag, men da de 12 slag var komne, kom der et pust og blev et rabalder i hele huset, og så lå de alle tre døde. Efter den tid stod der altid tre lys på stedet der ved Rugbjerg, og de står der endnu. ${ }^{35}$

Den typologiske fortælling om at lægge jord i sine sko, for dermed rent formelt (men ikke juridisk) at afgive en sandfærdig ed ${ }^{36}$, kendes i mange varianter i danske sagn fra den tid. En nærmest parallel fortælling til Haugaards sagn er overleveret fra Hjordkær Sogn ${ }^{37}$, og i Tang Kristen- sens Danske sagn er flere varianter af typen udgivet under overskriften "Falsk ed". ${ }^{38}$ Navneordet træde i trædeild er en dialektal (jysk) udtale af ordet trætte i betydningen 'strid, uenighed, skænderi' og lignende. ${ }^{39}$

Første del af benævnelsen på det overnaturlige lys i Haugaards sagn, "Bråvrup trædeild", er derimod mere kryptisk - i hvert fald ved første øjekast. Her kommer H.F. Feilberg (1831-1921) os til hjælp: I sin jyske ordbog under opslaget trædeild forklarer han, at "byen Braurup ligger ved landevejen mellem Tønder og Flensborg, syd for Tinglev". ${ }^{40}$ Således kan der kun være tale om landsbyen Broderup i Tinglev Sogn, der ligger tæt nord for den nuværende dansk-tyske grænse (se figur 3). ${ }^{41}$ Den lokale udtale af navnet går netop i retning af Tang Kristensens sta-

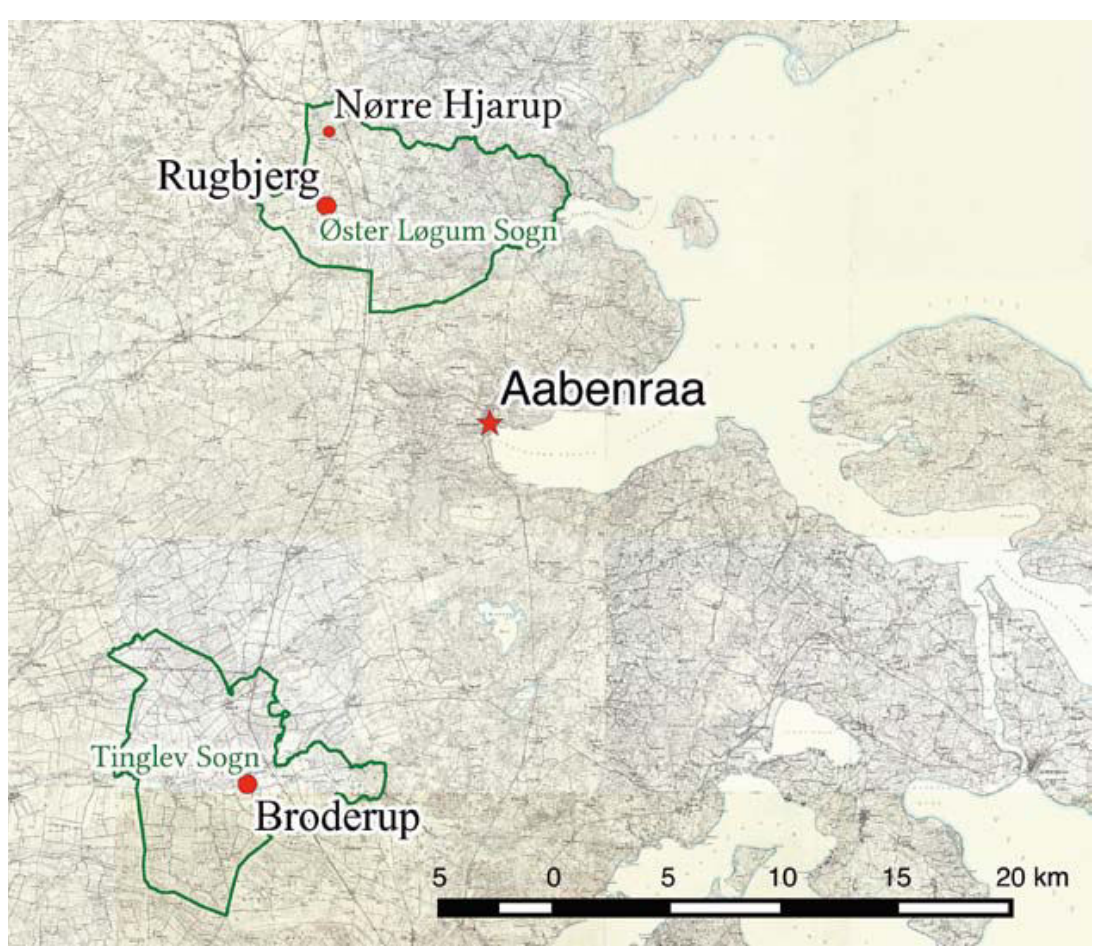

Figur 3: Haugaard blev født i Nørre Hjarup i Øster Løgum Sogn, og han boede som voksen $i$ Aabenraa. Hans sagn om »Bråvrup trædeild « foregår $i$ Rugbjerg $i$ hans fødesogn, men lysfænomenet er benæont efter landsbyen Broderup $i$ Tinglev Sogn omtrent 30 kilometer mod syd. Grafik: Martin Sejer Danielsen. Data: Styrelsen for Dataforsyning og Effektivisering (De preussiske målebordsblade, 1877-1920) og DigDag.dk (sognegrænser, vist for 1894). 
veform Bråvrup. ${ }^{42}$ Tang Kristensen optegnede og udgav gerne stednavnene meget udtalenært. ${ }^{43}$ Men hvordan har navnet på denne landsby sneget sig ind i betegnelsen på et overnaturligt fænomen, der ifølge Haugaard finder sted i Rugbjerg i Øster Løgum Sogn omtrent 30 kilometer væk fra Broderup?

Dette lader sig også forklare, for det er ikke Haugaards sagn, der er Feilbergs primære kilde til opslaget trædeild (om end Feilberg også viser kendskab til Haugaards sagn), men derimod et værk skrevet af aabenraaeren Frederik Fischer (1809-1871), der var urmager og redaktør i byen. I 1857 udgiver han for første gang sit værk Slesvigske Sagn, der trods titlen ikke er en sagnsamling, der kan sammenlignes med Tang Kristensens storværk Danske sagn. Fischer fremstiller derimod en række sagntraditioner, som han efter alle kunstens regler har omskrevet til hele noveller uden at angive, fra hvem traditionerne i øvrigt stammer. Værket fik stor popularitet blandt danske læsere i Nordslesvig, og derfor udkom det også i flere efterfølgende udgaver. ${ }^{44}$ Værket kunne således sagtens have stået i Haugaards bibliotek i en eller anden udgave.

Novellen om "Brauderup Trætteild" er allerede med i første udgave af Fischers værk ${ }^{45}$, men da den fylder 26 sider, vil jeg ikke citere den i fuld længde her. Men lad os prøve at sammenligne Haugaards sagn med indledningen til Fischers novelle, der lyder som følger:

Når man sidst hen i sommeren, da dagene allerede have aftaget og nætterne begynde at mørknes lidt, sildig om aftenen kommer nord fra til den højtbeliggende landsby Raubjerg [dvs. Rugbjerg i Øster Løgum Sogn], så ser man ofte langt nede i syd et lyspunkt, snart større snart mindre, og spørger man beboerne hvad det er der skimter frem igennem sommernattens dampe, så får man svaret: „De er Braurup Træreel. ${ }^{46}$

Haugaard formulerer sig ganske vist noget anderledes, og hans indledning er langt kortere, men den stilistiske opbygning i Haugaards indledning minder så meget om Fischers, at det er min overbevisning, at den er inspireret herfra, og hele Haugaards sagn kunne sagtens være en omdannet parafrase af Fischers novelle. Man fornemmer ligheden i den måde, hvor "man" spørger de lokale ind til lyset og får svaret: "Ja, det er Bråvrup trædeild". Haugaard har måske fundet Fischers poetiske opbygning særligt god og har - måske uden at være opmærksom på det - inddraget fortællestilen i sin egen fremførelse af sagnet. ${ }^{47}$
En teoretisk mulighed er, at inspirationen gik den anden vej. Som nævnt ovenfor ved vi med sikkerhed, at Haugaard boede i byen som udlært farversvend i 1860. Haugaard må altså have været lærling i tiden op til dette år, og det synes rimeligt at antage, at han allerede gik i lære som farver i byen kort tid efter konfirmationen i marts 1853. Den unge Haugaard kunne da i teorien have fortalt en eller anden version af sagnet for Fischer på et tidspunkt i perioden fra 1853 til 1857, dét år hvor Fischer udgiver sin bog i Aabenraa. Dog forekommer det mig usandsynligt, at det har været tilfældet. Det må have taget tid for Haugaard at udvikle sit fortælletalent og sit repertoire af sagn, og han har næp fortalt sagn for Aabenraas dansksindede elite så tidligt i sit liv. Uanset hvordan den nøjagtige kobling er mellem Haugaards sagn og Fischers novelle, er det stadig yderst relevant at spørge sig selv, hvorfor Haugaard interesserer sig lige netop for dette sagn.

\section{Juridiske og moralske love}

Lokaliteten har naturligvis gjort sagnet interessant for ham. Hvis han har læst flere af Fischers noveller, har han særligt bidt mærke i den om "Brauderup Trætteild", fordi novellen indledningsvis tager udgangspunkt i Rugbjerg i Haugaards eget fødesogn Øster Løgum. Som nævnt er det netop et karakteristisk træk ved genren sagn, at den primære handling geografisk henlægges i sagnfortællerens kendte landskab. Dette bliver særlig tydeligt, idet Haugaard ikke kun, ligesom Fischer, lader observationsstedet for lysfænomenet være i Rugbjerg. Haugaard har også ført lysfænomenet og hele fortællingen om processen op til denne landsby, og det til trods for at betegnelsen på fænomenet, "Bråvrup trædeild", er dannet af Broderup, der ligger så langt væk fra Rugbjerg.

Haugaard kommer også flere gange ind på retssager gennem sit repertoire af sagn. Særligt ét andet sagn er nærmest parallelt til sagnet om "Bråvrup trædeild": En mand sælger på markedet i Aabenraa to fede brune heste, men efter at have fået betaling for dem, så leverer han i stedet to magre sorte heste til køberen. Processen om denne sag varer flere år, og på tingstedet i Rødekro stævnes han til at sværge på, at det var de to sorte heste, han havde solgt. På grund af edens form bliver manden dog usikker på, om han tør sværge, men hans kone presser ham. Selvom modparten når at advare ham om, at Djævelen vil hente ham for at sværge falsk, vælger han alligevel at gøre dette. Umiddelbart efter kører han "som en besat" (af Djævelen?) fra tingstedet, hvorefter 
han farer vild og kører i Immervad $\AA$. Her drukner han sammen med konen, karle og heste, og de findes alle et halv år senere "i en ynkelig tilstand". 48

At sværge er en procedure, der udelukkende bygger på tillid, og derfor kan man utrolig nemt snyde systemet. Men bare fordi man kan snyde systemet og slippe af sted med det, så får det alligevel konsekvenser, når man gør det. Der er nemlig både juridiske og moralske love i samfundet, ${ }^{49}$ og i begge sagn modtager bedragerne en overnaturlig straf, fordi de har forbrudt sig mod de moralske love. At de står som lys på marken, er deres straf, for man kan ikke komme ind i Guds rige, når man har opført sig på den måde..$^{50} \mathrm{Og}$ bedragerne blev advaret: I sagnet om hestehandlen er det bedragerens offer, der advarer om de overnaturlige konsekvenser for at sværge falsk, og i sagnet om "Bråvrup trædeild" kommer præsten ind som moralens vogter: Gud giver dem muligheden for at råde bod på deres bedrag, men de vælger ikke at gøre det.

Egentlig tror jeg ikke, at Haugaard med sit sagn blot ønsker at løfte en moralsk pegefinger og sige, at man ikke må snyde systemet og tilrane sig andres jord. Det er relevant her at kigge på Haugaards eget møde med øvrigheden i Aabenraa. Tang Kristensen nævnte allerede i den korte levnedsbeskrivelse, som jeg citerede ovenfor, at Haugaard blev pålagt bøder på grund af sin danske fædrelandskærlighed, og i sine erindringer omtaler Tang Kristensen en konkret episode, som Haugaard var involveret $\mathrm{i}$ :

Manden var nærmest yderlig dansksindet og en stor hader af tyskerne. Da jeg kom, var han helt ophidset. En sypige havde syet og foræret ham et mindre dannebrogsflag, og i sin glæde over gaven var han sprungen hen og havde stukket det ud af indgangsdøren og svunget lidt med det. Det havde en seminarist eller lærer set, der netop i det samme gik længere oppe i gaden, og han havde meldt sagen til politiet. En gensdarm [sic!] var da kommen og havde dikteret ham en mulkt for "grober Unfug". 51

'Grober Unfug' er en juridisk betegnelse for forstyrrelse af den offentlige orden. ${ }^{52}$ Haugaard levede under den kulturelle fortyskningspolitik, der skærpedes mod slutningen af 1870'erne, men som i perioden 18981901 nåede sit højdepunkt med den strenge politik indført af overpræsident Ernst Mathias von Köller (1841-1928). ${ }^{53}$ Haugaard fortalte gan- ske vist sit sagn fire år før Köller-politikkens indførelse, men som Tang Kristensens citat vidner om, satte de preussiske gendarmer allerede her temmelig strengt ind over for de rød-hvide farver. ${ }^{54}$

Thomsen og Bech nævner også, hvordan Haugaard demonstrativt gik i kirke med et lille dannebrogsflag som bogmærke i sin salmebog ${ }^{55}$, og Bech gengiver følgende lille fortælling:

Mærkeligt nok syntes han [ $\mathrm{\jmath}$ : Haugaard] at have haft et vist frisprog hos de preussiske myndigheder, der ikke vovede at anklage ham for derved at gøre sig selv latterlige. Marten Refslund Poulsen [1874-1960] i Bovlund har fortalt mig, at han en dag før 1914 traf Haugaard på gaden i Aabenraa. Han råbte højt med de værste injurier mod tyskerne, så folk i nærheden ikke kunne undgå at høre det. ${ }^{56}$

Haugaard opfører sig altså trodsigt mod øvrigheden, og han tester grænserne for, hvor langt man kan gå i overskridelsen af den strenge lovgivning i forbindelse med fortyskningspolitikken. Grænsen mellem øvrighedens juridiske love og de dansksindedes ideologisk betingede moralske love har været kraftigt under forhandling blandt dansksindede slesvigere på dette tidspunkt i historien. Temaet i Haugaards sagn om netop forskellen mellem juridiske og moralske love, og ikke mindst hvori denne forskel består, er altså i sig selv interessant for dansksindede borgere i Aabenraa i 1890'erne.

En påmindelse om Guds moralske ret bevidnedes også to sagn forinden i Haugaards repertoire. Han fortæller her om to magiske syn, som en soldaterkammerat til Haugaards fader har haft. Det første syn varslede om den Første Slesvigske Krig (1848-1851), men det andet syn tager soldaterkammeraten som et varsel om Sønderjyllands fremtid: "[E]fter hans tykke [så han] en høj officer ride foran en lille trop danske soldater, og han hørte befalingsmanden sige: 'Er Gud med os, hvo kan da være mod os, vi har retten på vor side.' [...] Derfor var han trøstig i håbet om Sønderjyllands fremtid". ${ }^{57}$ Dette sagn er i hele Haugaards repertoire det tydeligste udtryk for hans danske sindelag.

I sagnet efter igen - og altså sagnet lige inden "Bråvrup trædeild"sagnet - vælger en mand, der er tilfangetaget af røvere, "at lægge sig ned og bede til Vorherre, at han ville hjælpe ham ud", hvilket også sker: Manden kommer hjem og melder sagen til øvrigheden, og soldaterne får fat på alle røverne, der bliver henrettet i Haderslev, hvorefter egnen 
blev fri for røvere. ${ }^{58}$ Også her har Haugaard fokus på øvrigheden, men i dette sagn optræder den kompetent og stærk, og den sørger for ro og orden, når der er rigtige forbrydelser at tage sig af..$^{59}$

\section{Skattegravning og begrænsede goder ${ }^{60}$}

Hvor Haugaards dansksindede væsen altså kan tolkes ind i visse af hans sagn, så er det, som allerede nævnt, ikke denne side af ham, der kommer hyppigst til udtryk $i$ hans repertoire af sagn. Her fornemmer man, at han havde et langt større fokus på et andet spørgsmål, nemlig et om rimeligheden, eller manglen på samme, i fordelingen af goderne i det stærkt klasseopdelte samfund, som han var opvokset i.

Haugaard fortæller Tang Kristensen et sagn om skattegravning. I sagnet er der meget direkte tale, og Tang Kristensen har i flere tilfælde bevaret dialektale ord og vendinger, også i den trykte version af sagnet. Derfor har jeg i slutnote 61 lavet en omskrivning til rigsdansk. Tang Kristensens version lyder som følger:

En mand på Hyrup mark har fortalt mig følgende: Der kom en jøde ned til en gammel kone på Rangstrup mark, Agerskov sogn som sad og brændte kaffebønner, og bød sine varer fal. $\mathrm{Nu}$ havde hun en tørvekasse, som der stod nogle bogstaver på. Så spørger jøden hende ad, hvor hun havde fået den fra. »Den har såmænd fader og mig gravet op ude i vor have, da vi begravede nogle Kartofler. « - »Ved I, lille mo'r, hvad der står på den? « siger han. - »Nej, hvor skulle æ vide det fra, vi er ikke så højt studerede, te vi kan løjjs de streger og det kram, der står. «- »Ja, da står der såmænd, lille mo'r, te der er en kasse neden under den den[!] igen, og den gemmer 30000 mark kurant.« - »A, snak har vi nok af «, siger konen, »bild os ikke sådan noget ind.« - »Ja, ven I tykkes om det«, siger han, »så vil æ blive her nogle dage, og så vil æ bekoste det gravet op, dersom æ må få min del af det«. Manden stod ude i laden og tarsk, og konen taler så til datteren: »Mitte (つ: Marie), tal på fa'r og lad ham komme ind.« Så kom han. »Hvad tykkes du om det, den fremmede mand siger.? Han vil blive her og grave i vor have på hans egen bekostning, dersom han må få hans part af det, han finder. Må han grave for dig? « - »Ja, såmænd må han så, men det meste vil æ da ha', hvis der er noget. Her er Hans og Peter ovre, de har ikke noget at bestille, så kan de jo få arbejde«. De fik så det hele stilt an og kommer til at grave. Lav de kom så seks alen ned, siger de: »Nu vil vi ikke grave længere ned, for der er ingen kasse. « Men da lod jøden en blank daler glide ned i hånden af dem, og da de så havde gravet en halv alen til, så kom kassen til syne. Nu kan I stole på, der blev glæde. De drog kassen op, og den indeholdt alle pengene i guld. Men på den kasse stod der skrevet, at der var én længere nede, der indeholdt lige så meget. Hele byens folk blev så samlet, og efter to timers arbejt havde de den oppe også. Men så fik regeringen nys om sagen, og den ville have det halve, og jøden ville have det andet halve. Det kom så til en proces, og den varede i seks år, og endtes med, at der ikke var mere end 4000 gamle mark i behold til folkene. Så solgte de deres gård og drog til Jylland. ${ }^{61}$

Fra sine feltnoter har Tang Kristensen lavet lidt om i teksten. Eksempelvis har han gjort Haugaards oprindelige formulering, der i feltnoterne lyder "Ja så gu må han så"62, mindre stødende: "Ja, såmænd må han så". Hertil har Tang Kristensen flyttet rundt på nogle sætninger og tilføjet nogle ord, så det bliver tydeligere, hvornår Haugaard benytter direkte tale, og hvem ordene lægges i munden.

Konen, der sidder på Rangstrup Mark, tilhører landbosamfundet, men hendes stand er ikke helt entydig: Mod slutningen sælger de deres "gård" og drager til Jylland, hvilket jo peger på folk fra gårdmandsstanden; særligt hvis Hans og Peter skal forstås som egentlige karle. Dog synes den måde, hvorpå konen sidder og brænder kaffebønner, at pege på et medlem af kådnerstanden - altså Haugaards egen stand - hvor man som nævnt ofte har måttet supplere sin indkomst med forskellige former for bibeskæftigelse, jævnfør hvordan Haugaards egen fader netop stod optegnet som lønarbejder.

I traditionelle bondesamfund møder man, ifølge den amerikanske antropolog George M. Foster (1913-2006), den grundindstilling, at samfundet er et lukket system af begrænsede goder. Derfor opleves en persons pludseligt opståede rigdom og succes som en trussel mod alle andre i samfundet. ${ }^{63}$ Man kan billedliggøre forestillingen med en lagkage, som en gruppe mennesker skal deles om. Den kan skæres ud i større eller mindre stykker, og kommer nogen pludseligt i besiddelse af et stort stykke kage, er der nødvendigvis tilsvarende mindre for resten at deles om.

Derfor sanktioneres mennesker, der opnår pludselig rigdom, af lokalsamfundets øvrige medlemmer med alt fra ondskabsfuld sladder 
til egentlig fysisk afstraffelse. ${ }^{64}$ Så langt forklarer Fosters teori omtrent baggrunden for den opførsel, vi på dansk kalder for janteloven, der forstås som et "sæt af leveregler i et (mindre) samfund som foreskriver ydmyghed og tilbageholdenhed, især hvis man har bedre evner, mere succes, flere penge el.lign. end flertallet" ${ }^{65}$

John Lindow har observeret hvordan man i svenske sagn om skattegravning typisk ikke får fat på skatten, eksempelvis fordi skattegraverne bryder med den magiske regel, at man ikke må tale under skattegravning. Dette tolker Lindow blandt andet som et billede på, hvordan goderne i samfundet netop betragtes som konstant, en status quo der ikke kan ændres på. ${ }^{66} \mathrm{I}$ danske sagn om skattegravning făr skattegraverne typisk heller ikke fat på skatten ${ }^{67}$, hvilket kan tolkes på samme måde som Lindows svenske eksempler. Finder nogen en skat og bliver rige, er det nemlig et billede på en verdensopfattelse, hvor samfundet består af ubegrænsede goder, altså at man kan forøge sin velstand uden at gøre det på bekostning af andre. ${ }^{68}$ Men i Haugaards sagn finder de netop skatten!

\section{Ændringer i den økonomiske status quo}

Jøden i Haugaards sagn tror på de ubegrænsede goder, og han forstår at gribe chancen for at tjene penge, når muligheden byder sig. I Haugaards samtid talte man ikke just pænt om jøderne, og deres optræden i sagn er ofte negativ, hvilket Haugaards fremstilling af ham også giver udtryk for: Jøden er snu, og han formår at snyde bønderne, så de nærmest intet får ud af skattegravningen. Men Haugaard ser ikke egentlig bønderne som ofre for jødens opførsel: Bønderne lader sig nemlig snyde, og Haugaard fremstiller dem som uuddannede ("vi er ikke så højt studerede, te vi kan løjjs de streger og det kram, der står"), en smule grådige ("men det meste vil æ da ha', hvis der er noget") og smådovne ("Her er Hans og Peter ovre, de har ikke noget at bestille").

I Haugaards samtid er den økonomiske status quo netop ved at ændre sig: Blandt andet stigende priser på fødevarer som korn og kvæg medførte et økonomisk opsving i 1840'erne og 1850'erne ${ }^{69}$, netop den periode hvor Haugaard har levet som barn og ung i Nørre Hjarup. Dog har det ikke været kådnersønnen Haugaard, der fik noget ud af det økonomiske opsving: Han har stået på sidelinjen og observeret, hvordan gårdmandsstanden øgede sin velstand. Velstandsforøgelsen var nemlig synlig, fordi gårdmændene eksempelvis renoverede deres gårde. ${ }^{70}$ Den unge Haugaard har altså opdaget, at samfundet indeholder flere goder end det traditionelle landbosamfund havde øje for. Han har opdaget, at der på en måde er ubegrænsede goder i samfundet. Derfor er det ikke noget problem for Haugaard, at sagnkaraktererne finder skatten - det gør de også i det næste sagn, som Tang Kristensen har optegnet efter ham $^{71}$ - spørgsmålet er snarere, hvem der får glæde af de ubegrænsede goder, og hvorfor de gør det.

Haugaard fremstiller bønderne som skeptiske og modvillige, da jøden påstår, at der ligger en skat begravet i deres egen have. Konen slår det hen som "snak" ( ("Nu vil vi ikke grave længere ned, for der er ingen kasse"). Konen og hendes ligesindede er i sagnet præget af tankegangen om det økonomiske status quo, hvor man ikke forestiller sig, at goderne er ubegrænsede. Dette verdenssyn oplever Haugaard som gammeldags, men han er ikke upåvirket af det.

I eftertidens Aabenraa bliver Haugaard husket som pengeglad. ${ }^{72}$ Tang Kristensen beskriver ham i den lille levnedsbeskrivelse (citeret ovenfor) som yderst påholdende, og det er ikke uden en vis grad af mishag, når den selv temmelig påholdende Tang Kristensen erindrer, hvordan Haugaard "ymtede [...] om, at han skulle have lidt betaling for, hvad han fortalte". Det blev afregnet ved, at Tang Kristensen lovede Haugaard en af sine bøger, "men han glemte heller ikke at kræve mig for den", erindrer Tang Kristensen. ${ }^{73}$ Bogen har Haugaard kunnet omsætte til penge ved at leje den ud for en ringe betaling fra sit private lejebibliotek, hvor man også kunne købe en kop kaffe. ${ }^{74}$

Haugaard tegner sig således som et meget komplekst menneske, der på den ene sider viser tegn på at komme fra fattige kår, og på den anden side har forsøgt at ændre på sin sociale arv. Haugaard har gennem sit liv forsøgt at få del i de ubegrænsede goder, og sikkert derfor tog han til byen og gik i lære som farver. Men den bogligt begavede Haugaard, der forlader sin hjemegn og prøver lykken i byen, har næppe mødt stor forståelse fra sine forældres og bedsteforældres generation på landet.

Folkene i sagnet ender jo også med at sælge deres gård og rejse til "Jylland". I konteksten må der nødvendigvis være tale om Nørrejylland, altså nord for Kongeåen, så folkene udvandrer altså til Kongeriget. Så langt minder denne flytning jo om, hvordan mange mennesker netop udvandrede fra Slesvig i perioden 1868-1885 for, som Haugaard, at prøve lykken et andet sted. Mange rejste til Amerika eller andre oversøiske mål, mens nordslesvigere med danske sympatier netop gerne udvandrede til Danmark. ${ }^{75}$ 


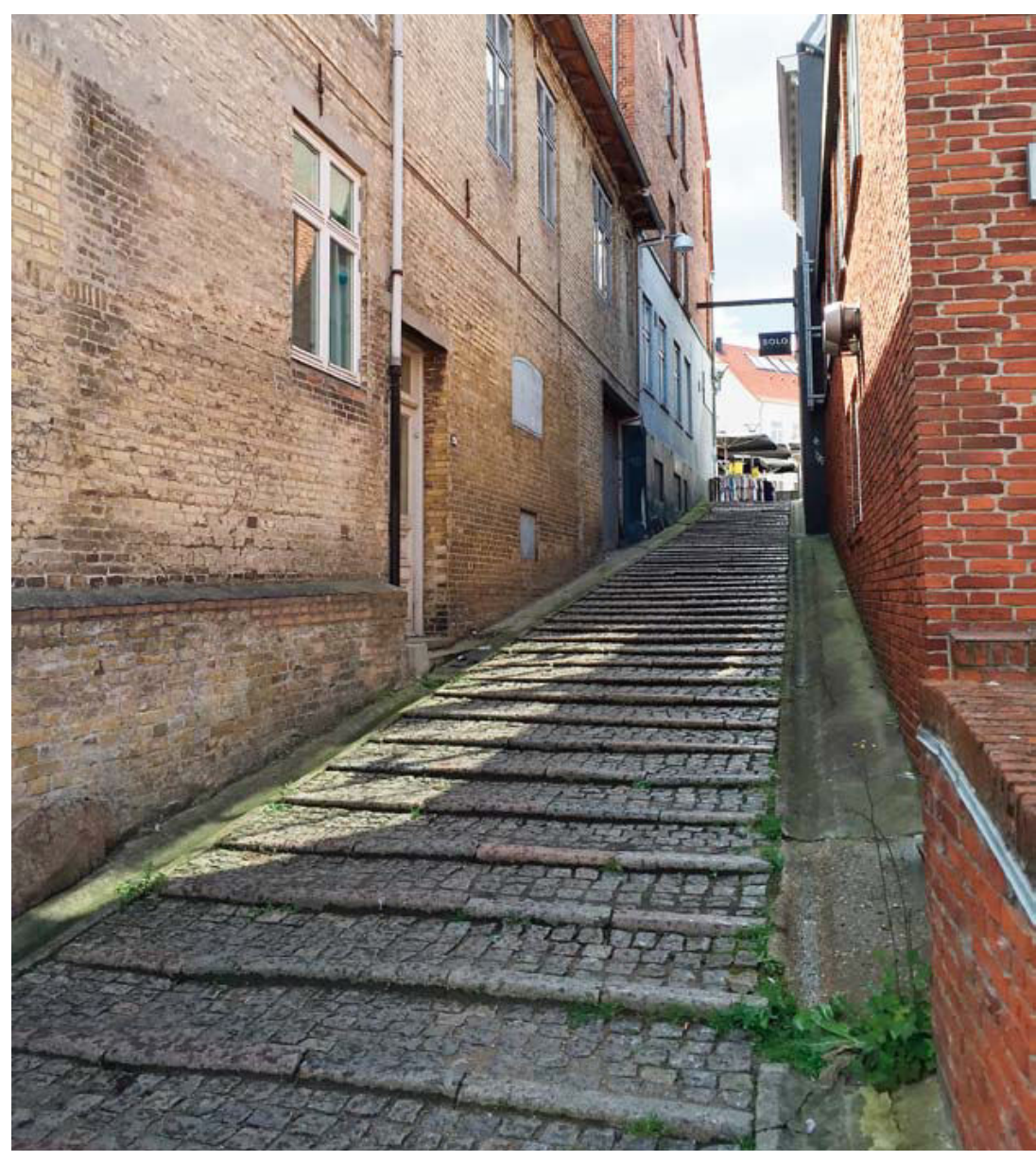

Figur 4: Siden 1862 (se figur 2 ovenfor) er Aabenraa blevet meget større, og Rebekkagangen er blot en sti med trapper der bevxger sig opad fra Madevej over Skrænten til gågaden på Ramsherred. Haugaards lille hus er for længst forsvundet. Billedet viser den øverste halvdel af stien fra Skrænten op mod Ramsherred. Foto: Martin Sejer Danielsen, august 2016 .

Fra barnsben havde Haugaard altså lært at tjene en skilling, hvor han kunne, og han havde lært at passe på sine penge. Med denne erfaring i bagagen, havde han i Aabenraa udviklet sig til en hel entrepreneur, som han sad der på sine ældre dage som pensionist $i$ det lille hus på Rebekkagangen og tjente til dagen og vejen ved at leje bøger ud og sælge kaffe - og indirekte ved at fortælle sagn.
Thomsen erindrer fra sin barndom, hvordan Haugaard fortalte mærkelige historier om nogle visitter, som han efter eget udsagn aflagde årligt hos de kongelige på Fredensborg nord for København. Til at understøtte disse fortællinger påstod han at være i besiddelse af forskellige artefakter, som han ved disse lejligheder havde fået, eksempelvis en tot hår fra prinsesse Maries kat, en frynse af Caroline Mathildes saddel og en kongelig kraveknap. ${ }^{76}$

Når Thomsen fremhæver netop dette aspekt om Haugaard, er det igen for at fremhæve hans danske patriotisme. Men hendes erindring om disse fortællinger vidner alligevel om, hvordan sagnfortælling har været del af pakken, når man besøgte Haugaard. Han var en fremragende sagnfortæller, og derfor kunne han ligeså godt forsøge at tjene penge på sit talent.

Man må sætte spørgsmålstegn ved, om Haugaard faktisk ændrede på sin sociale status: Som lønansat farversvend i byen har han stadig tilhørt et klassetrin, der har mindet om kådneren på landet: Når industrien havde fremgang, hvilket faktisk synes at have været tilfældet for Festesens klædefabrik i årene frem mod 1879-188077, er det fabriksejerne, der øger deres velstand, ikke håndværkersvendene. Disse fandt derimod typisk sammen med arbejderne i den socialdemokratiske bevægelse; en bevægelse der i Aabenraa findes vidnesbyrd om fra 1870'erne. ${ }^{78}$

Bøndernes halvhjertede bestræbelser i Haugaards sagn kommer dem netop heller ikke til gode: Det hele trækker ud i en lang retssag, og jøden og regeringen får det meste af skatten. Tematikken om retssager genkender vi jo i øvrigt fra sagnet, som jeg analyserede ovenfor, og vi fornemmer igen, hvordan Haugaard ikke har stor tiltro til øvrigheden. Hertil viser han også sin grundlæggende utilfredshed med de reelle muligheder for at bryde med sin sociale arv; en utilfredshed som han udfolder meget tydeligere $i$ andre af sine sagn, eksempelvis i det næste sagn, Tang Kristensen har optegnet efter ham. ${ }^{79}$

\section{Konklusion}

Sagnene, som vi læser dem i Tang Kristensens store korpusværker og andre steder, stammer fra levende, tænkende og følende individer, der huskede på og fortalte sagnene, fordi disse fortællinger var relevante og skabte betydning for dem og deres tilhører i den samtid, som sagnfortællingen foregik $i$. Når man går til sagnene med dette teoretiske udgangspunkt, opdager man, hvordan de er mættet med ideologi. Chri- 
stian C. Haugaard er bare ét eksempel på en fortæller, der gennem sine sagn kommenterer på den politiske, sociale og økonomiske samtid, han lever i.

Haugaards nationalpolitiske standpunkt kommer sjældent direkte til udtryk i hans sagn, hvilket egentlig er overraskende, når eftertiden husker ham for at have været "nærmest yderlig dansksindet", som Tang Kristensen formulerede det. ${ }^{80}$ Til gengæld fornemmer man det forhold til den tyske øvrighed, som en dansksindet slesviger i Aabenraa har haft, eksempelvis er Haugaard optaget af temaet om forskellen mellem juridiske og moralske love.

Men hverdagen består af andet end de store nationalpolitiske spørgsmål. Haugaard fortæller således flere sagn, der indeholder temaet om fordelingen af goderne i samfundet. Denne problematik optog mange i Haugaards samtid, jævnfør hvordan en socialdemokratisk bevægelse kan dokumenteres fra 1870'ernes Aabenraa. I sagnet om skattegravning viser Haugaard tegn på at være påvirket af nyere tiders tankegange om muligheden for - eller drømmen om - at bryde med sin sociale arv, og derfor gør han lidt grin med sine forældres og bedsteforældres generation i landbosamfundet, måske endda med kådnerstanden, som han selv kommer fra.

Jeg håber, at jeg med denne artikel kan bidrage til at genintroducere sagnene som kilde i den lokalhistoriske forskning i Sønderjylland og andre danske egne. Sagnene er meget mere end kuriøse beretninger om fortiden, som man ikke rigtig kan fæstne lid til. ${ }^{81}$ Med den rette metode kan sagnene føres tilbage til sin oprindelige kontekst, og således kan de bidrage til en forståelse af befolkningens eget forhold til den samtid, de levede i.

\section{KILDER}

Utrykte

Dansk Folkemindesamling, Det Kgl. Bibliotek, København:

DFS 1929/16 (Tang Kristensens primære feltnoter, de såkaldte Dagbøger)

DFS 1929/102 (uudgivet manuskript til en tredje række af Jysk Almueliv)

Rigsarkivet, Aabenraa:

Kirkebøgerne fra Øster Løgum og Aabenraa sogne.*

Folketælling fra Øster Løgum Sogn 1845 (Del af folketællingen Sønder Rangstrup Herred og Bolderslev Fogderi Rise og Øster Løgum Sogne).

Folketælling fra Aabenraa 1860 .

Folketællinger foretaget af Stadtbezirk Apenrade i 1885, 1890, 1895, 1900, 1905, 1910

Aabenraa Personregisterfører: Døde, biregister.* $^{*}$

\section{LITTERATUR}

Adriansen, Inge: Fædrelandet, folkeminderne og modersmålet: Brug af folkeminder og folkesprog i nationale identitetsprocesser især belyst ud fra striden mellem dansk og tysk i Sønderjylland, Sønderborg 1990. (Skrifter fra Museu

Alver, Brynjulf: "Historiske segner og hiAlver, Brynjulf: "Historiske segner og hi-
storisk sanning", Norveg 9, 1962, s. 89116.

Bech, Carl Johan: "Gamle Dages „Originaler"", Aabenraabogen: Byen som den lever i Mindet 1945: Befrielses-Aaret og 25-Aaret for Genforeningen, red. Carl Johan Bech, Aabenraa 1945, s. 107-124.

Bech, Carl Johan: "Det gamle Aabenraa og dets originaler: Haugaard, der døde a glæde på afstemningsdagen", Hejmdal 29.10.1956, s. 4-5.

Becker-Christensen, Henrik: "Fra "mod hinanden" til "med hinanden " 1918 2008", Sønderjyllands historie 2, red. Hans Schultz Hansen, Lars N. Henningsen og Carsten Porskrog Rasmussen, Aabenraa 2009, s. 241-472.

Bergstrøm-Nielsen, Henrik, Peter Jürgensen og Preben Späth under medvirken
* Tilgængelig gennem Arkivalieronline: https://www.sa.dk/da/sidebar_widget/ ps://www.sa.dk/da/sidebar_widget/
arkivalieronline/ (sidst set 21.12.2017).

Trykte

Sønderiydsk Maanedsskrift 1930-1931.

Tang Kristensen, Evald: Sagn og overtro fra

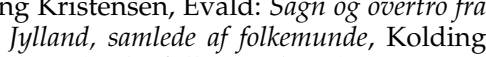
Jylland, samlede af folkemunde,
1886. (Jyske folkeminder 8.)

Tang Kristensen, Evald: Danske sagn, som de har lydt i folkemunde 1-7, Århus 1892-
distensen, Evald: Danske sagn, som de har

Tang Kristensen, Evald: Danske Sagn som de har lydt $i$ Folkemunde, Ny Række 1-6, fra og med bind 3 og frem udgivet af Johannes Evald Tang Kristensen, København 1928-1939.

Flensborg Avis, Nr. 41, 52. Årg., 18.02.1920. Tilgængelig gennem http://www.fla. de/ePaper (sidst set 10/1-2018).

af Birgit Lohse: Tysk-Dansk Ordbog, København 2005. (Gyldendals Røde Ordbøger.)

Boberg Inger M.: Dansk folketradition $i$ tro og digtning og deraf afhængig skik. Udg. af Iørn Piø. København 1962 . Udg. af lørn Piø. København 1962. (Dan-
marks Folkeminder 72.) Danielsen, Martin Sejer: Da Lille Peder fik Per Lilles Eng i faddergave: Et studie af stednavneforklarende elementer $i$ den folkloristiske genre sagn, ph.d.-afhandfolkloristiske genre sagn, ph.d.-afhand-
ling, Københavns Universitet 2017. ling, Københavns Universitet 2017.
URL: http://static-curis.ku.dk/porURL: http://static-curis.ku.dk/portal/files/186419048/Ph.

Danielsen, Martin Sejer: "Per Lilles Eng - og den troværdige fejlslutning", Mànedens navn på navn.ku.dk, 1 . februar 2018, URL: http://navn.ku.dk/maanedens_navn/per-lilles-eng (sidst set 01.02.2018).

$\mathrm{DDO}=$ Den Danske Ordbog, udgivet af Det Danske Sprog- og Litteraturselskab. Online udgave: http://ordnet.dk/ddo (sidst set 20.12.2017).

DS 5 = Sønderiyske Stednavne III. Tønder Amt med dele af Ribe Amt, udgivet af 
Stednavneudvalget, København 1933 (Danmarks Stednavne 5)

Erslev, Kristian: Grundsætninger for historisk Kildekritik. København 1892.

Feilberg, H.F.: Bidrag til en ordbog over jyske almuesmål 1-4, Kjøbenhavn 1886-1914

Feilberg Jørgensen, Anders: Sprogforenin-
gen gennem 100 år: 1880-1980, Søndergen gennem
borg 1980.

Fischer, Frederik: Slesvigske Sagn. Aabenraa 1857

Foster, George M.: "Peasant Society and the Image of Limited Good", American Anthropologist 67, 1965, s. 293-315.

Foster, George M.: "A Second Look at Limited Good", Anthropological Quarterly $45.2,1972$, s. $57-64$

Frandsen, Svend B.: Sønderiylland: Sagn og virkelighed omkring år 1900: I Evald Tang Kristensens fodspor, [2010].

Grimm, Jacob og Wilhelm Grimm: Deutsche Sagen 1-2, Berlin 1816-1818.

Grüner-Nielsen, Hakon: "Sønderjyske Folkeminder", Fortid og Nutid 3, 1921, s. $17-40$.

Hansen Nielsen, Leif: Ad Industriens Vej: Studier $i$ den slesvig-holstenske indust 1864-1914 med sxritig henblik pa Nordslesvig, Aabenraa 2007. (Skrifter udgivet af Historisk Samfund for Sønde jylland 97.)

Holbek, Bengt: Interpretation of Fairy Tales: Danish Folklore in a European Perspective, Helsinki 1987. (FF Communication 239.)

Jensen, Charlotte S.H.: "sagn", sitet Den Store Danske, sidst redigeret 27.12.2011. URL: http://denstoredanske.dk/index php?sideId=154385 (sidst set 25.01.2018)

Johansen, Thomas: "»Her er ret skjel Et studie i tyveri af markiord i dansk sagnlitteratur", Danske Studier 1997, s. 5-14.

Lindow, John: "Swedish Legends of Buried Treasure", The Journal of American Folklore Vol. 95, No. 377, 1982, s. 257279 .

ODS = Ordbog over det danske Sprog, udgivet af Det Danske Sprog- og Litteraturselskab. Online udgave: http:// / ordnet. selskab. Online udgave: http:
$\mathrm{dk}$ /ods (sidst set 21.12.2017)

Olrik, Axel: Nogle grundsxtninger for

sagnforskning, udg. af Hans Ellekilde,
sane sagnforskning, udg. af Hans Ellekilde,
København 1921. (Danmarks Folkeminder 23.)
Oring, Elliott: "Legendry and the Rhetoric of Truth", The Journal of American Folklore, Vol. 121, No. 480, 2008, s. 127-166. Pentikäinen, Juha: "The Dead without Status", Temenos 4, 1969, s. 92-102.

Pentikäinen, Juha: "Repertoire Analysis", Folk Narrative Research: Some Papers Presented at the VI Congress of the International Society for Folk Narrative Research red. Juha Pentikäinen og Tuula Juurikka, Helsinki 1976, s. 262-272. (Studia Fennica 20.)

Pentikäinen, Juha: Oral Repertoire and World View: An Anthropological Study of Marina Takalo's Life History, Helsink 1978. (FF Communications 219. .)

Schmidt, August [F.]: "C. C. Haugaard og Folkeminderne", Hejmdal 27.12.1956, s. 2 Schultz Hansen, Hans: Det sønderyyske landbrugs historie: 1830-1993, Aabenra Samfund for Sønderjylland 72.) Schultz Hansen, Hans: "Nationalitetskamp og modernisering 1815-1918" Schult Schultz Hansen, Lars N. Henning-
sen og Carsten Porskrog Rasmussen, sen og Carsten Porskrog

Skifter Andersen, Erik: Registrant over ejendomme $i$ Aabenraa 1700 til 1920, Aabenraa 2012.

Tang Kristensen, Evald: Minder og Oplevelser 1-4, Viborg 1923-1928.

Tang Kristensen, Evald, Peter Olsen og Erik Høvring Pedersen: Gamle kildevald: Portratter af danske eventyrfortællere og visesangere fra århundredskiftet København 1981.

Tangherlini, Timothy R.: Interpreting Legend: Danish Storytellers and Their Repertoires, New York \& London 1994. (Milman Parry Studies in Oral Tradition.)

Tangherlini, Timothy R.: "Rhetoric, Truth and Performance: Politics and the Interpretation of Legend", Indian Folklife 25, 2007, s. 8-12.

Tangherlini, Timothy R.: "The Beggar the Minister, the Farmer, his Wife and the Teacher: Legend and Legislative Reform in Nineteenth-Century Denmark", Legends and Landscape: Articles Based on Plenary Papers Presented at the 5th Celtic-Nordic-Baltic Folklore Symposium, Reykjavík 2005, red. Terry Gunnell, Reykjavik 2008, s. 171-195.
Tangherlini, Timothy R.: Danish Folktales, Legends, \& Other Stories: The Danis Folklore Nexus, Digital Materials, Se attle and Copenhagen 2013.

Thomsen, Ingeborg [Refslund]: "Hvem var Hovgaard? De Lærde er uenige", Sønderjydsk Maanedsskrift 16, 1939-1940 s. $230-232$

\section{NOTER}

1 Efter redaktionens ønske er alle citate normaliserede efter moderne retskrivning uanset om de stammer fra primære eller sekundære kilder.

2 Grimm og Grimm 1816-1818, 1, s. V.

3 Jf. Tangherlini 1994, s. 13-15.

4 Erslev 1892, s. 24-27; Olrik 1921, s. 124127.

5 Alver 1962.

6 Se især Oring 2008

7 Jf. f.eks. Tangherlini 1994, s. 5-6.

8 En forskningshistorisk funderet indføring i genren sagn kan fås hos Tangherlini 1994, s. 3-22.

9 Tangherlini 2007; 2008.

10 Holbek 1987; Tangherlini 1994, 2008, 2013; Danielsen 2017.

11 I Danielsen 2017, s. 137-203, tegner jeg en detaljeret biografi af Christian C. Haugaard og foretager løbende analyser af eksempler fra hans repertoire a sagn. Jf. Danielsen 2018

12 Jf. Adriansen 1990, s. 87. Tang Kristensen foretog i alt otte rejser syd for Kongeåen i perioden 1886-1910. Disse beskriver han forskellige steder i sit erindringsværk Minder og Oplevelser (Tang Kristensen 1923-1928) bind 3 og 4, se Danielsen 2017, s. 123, tabel 1, for nøjagtige sidehenvisninger. Svend B. Frandsen ([2010]) har desuden kompileret og udgivet disse beskrivelser

13 Tang Kristensen 1923-1928, 4, s. 47, 250 og 296.

14 Ibid., s. 296. Billedet er tidligere trykt i Tang Kristensen, Olsen m.fl. 1981, s. 137

15 DFS 1929/102, $\mathrm{VI}^{3}:$ 30. Beskrivelsen kan læses i sin oprindelige form i Danielsen 2017, s. 307.

16 Øster Løgum Sogns kirkebog, hovedministerialbog, fødte m.m. 1776-1845, s. 234.
Worsøe, Hans H.: "Tiden 1864-1920", Åbenrå Bys Historie III, red. Johan Hvidtfeldt og Peter Kr. Iversen, København 1974 s. 5-126. (Skrifter, udgivne af Samfund for Sønderjylland 25.

17 Folketælling 1845, Øster Løgum Sogn; Øster Løgum Sogns kirkebog, hovedministerialbog, konfirmationer 18431898 , s. 36.

18 Schultz Hansen 1994, s. 88-89; samme 2009, s. 51

19 Folketælling 1845, Øster Løgum Sogn. Folketælling 1860, Aabenraa Købstad.

22 Folketællinger foretaget af Stadtbezirk Apenrade den 1. (eller 2) december i årene $1885,1890,1895,1900,1905$ og 1910 (Hans Schultz Hansen skal have tak for a helpe mig med at finde tak for at hjolpe mig med at finde og bestille disse folketwilinger til gennemsyn). Aabenraa Personregisterfører, Sterbe-Nebenregister (døde, biregister), Jahrgang 1920, Nr. 25. Erik Skifter Andersen, 2012, s. 135, registrerer, at "Haugaard, Chr. C." skulle bo pa Gildegade 1 som købmand. Dette fremgår ikke af de bevarede folketællinger, så både adressen og erhvervet mà bero på en misforståelse fra Skifter Andersens side.

23 DFS 1929/16.

24 Konceptet i en folkloristisk repertoireanalyse forbindes særligt med finske Juha Pentikäinen (1976 og 1978). I sin analyse af danske sagn følger Timothy R. Tangherlini - se især 1994 og 2013 de samme principper. Det samme gør eg 1 min ph.d.-afhandling (Danielsen 2017)

25 I appendikset til min ph.d.-afhandling (Danielsen 2017, s. 259 ff.) findes en tekstkritisk udgave af Haugaards samlede repertoire af primært sagn, som de sår optegnet i feltnoterne, ligem de (id optegnede. 26 Aabenraa Sogns kirkebog, kontraministerialbog, døde 1909-1934, s. 53v.; 
Aabenraa Personregisterfører, SterbeNebenregister (døde, biregister), Jah gang 1920, Nr. 25

27 Nekrologen "Haugaard død" i Flensborg Avis 18.02.1920.

28 Thomsen 1940; Bech 1945, s. 109-111; samme 1956. August F. Schmidt supplerer senere samme år Bechs artike ved at pege på Haugaards folkloristiske bidrag (Schmidt 1956).

29 Becker-Christensen 2009, s. 254-257.

30 Thomsen 1940, s. 232; Bech 1945, s. 110 samme 1956, s. 5; Worsøe 1974, s. 86

31 Feilberg Jørgensen 1980, s. 25-32.

32 Thomsen 1940, s. 231.

33 Tang Kristensen $1923-1928,4$, s. 47 ; Bech 1945, s. 109, samme 1956, s. 4.

34 ODS, kneppe ${ }^{3}$, betydning 1.

35 Tang Kristensen 1892-1901, 6, nr. 115. Versionen fra feltnoterne kan læses $\mathrm{Da}$ nielsen 2017, s. 283-284 (HAU20). Det indskudte "[end]" $i$ citatet er inspireret af feltnoterne og erstatter et fejlskrevet "og" i den udgivne version.

36 Johansen 1997, s. 7.

37 Tang Kristensen 1886, s. 204, nr. 343.

38 Tang Kristensen 1892-1901, 6, s. 33 ff.; samme 1928-1939, 6, s. $18 \mathrm{ff}$

39 ODS, trætte ${ }^{1}$. Se også opslaget træde hos Feilberg 1886-1914, 3, s. 870

40 Feilberg 1886-1914, 3, s. 871.

41 Fra Broderup i Tinglev Sogn fortælles netop sagn om "Broderup Trædeild" hvilket to overleveringer udgivet i Sø derjydsk Maanedsskrift 1930-1931 (s. 14 og 158) vidner om. Her sættes sagnene i øvrigt i forbindelse med stednavnet Trædemark (DS 5, s. 664)

42 En udtaleform af stednavnet fremgår af DS 5, s. 645

43 Danielsen 2017, s. 130-134.

44 Grüner-Nielsen 1921, s. 31-32.

45 Fischer 1857, s. 23-48.

46 Ibid., s. 23.

47 En teoretisk mulighed foreligger, at Haugaard ikke selv har læst sagnet, men at der har været et eller flere mundtlige mellemled. Noget sådan er dog nærmest umuligt at redegøre for.

48 Tang Kristensen 1892-1901, 6, nr. 113; Danielsen 2017, s. 289-291 (HAU26).

49 Jf. Johansen 1997, s. 7-8.

50 Juha Pentikäinen, 1969, s. 97, fremstiller en model for, hvilke årsager der nordiske sagn gør sig gældende, når folk ender som spøgelser. Eksempelvis er forskellige former for kriminell handlinger, så som at afgive falsk ed oplagte årsager.

51 Tang Kristensen 1923-1928, 4, s. 47.

52 Bergstrøm-Nielsen, Jürgensen m.fl. 2005 , s. 1820

53 Schultz Hansen 2009, s. 200-204, 217-219.

54 Jf. ibid., s. 201 (billedteksten).

55 Thomsen 1940, s. 231; Bech 1945, s. 109; samme 1956, s. 4

56 Bech 1956, s. 4

57 DFS 1929/16, s. 6829a. Da Tang Kristensen har lavet om $i$ sagnet $i$ den udgivne version (Tang Kristensen 19281939, 2, nr. J 113), citerer jeg her direkte fra feltnoterne, om end jeg forsigtigt har normaliseret forkortelser, retstavning og tegnsætning. Den oprindelige 281-282 (HAU18).

58 Tang Kristensen 1892-1901, 4, nr. 1581 Danielsen 2017, s. 282-283 (HAU19).

59 Jf. Danielsen 2017, s. 166-171, hvor jeg analyserer et af Haugaards sagn med udgangspunkt i en lignende tematik.

60 Sagnet i dette afsnit analyserede jeg også Danielsen 2017, s. 175-180. Dog har jeg i nærværende artikel ændre lidt i sagnets analyse. Jeg vil her takk Johnny G.G. Jakobsen for gode input. 61 Tang Kristensen 1892-1901, 3, nr. 2199. dansk: »En mand på Hyrup Mark ha fortalt mig følgende: Der kom en jøde ned til en gammel kone på Rangstrup Mark i Agerskov Sogn. Hun sad og brændte kaffebønner, og jøden tilbød hende at købe sine varer. $\mathrm{Nu}$ havde hun en tørvekasse, som der stod nogle bogstaver på. Så spørger jøden hende, hvor hun havde fået den fra. "Den har min mand og jeg såmænd gravet op ude i vores have, da vi lagde kartofler" - "Ved De, lillemor, hvad der stå på den kasse?" siger han. - "Nej, hvor skulle jeg vide det fra? Vi er ikke sà højt uddannede, at vi kan lere de streger og de ting der står" - "Ja der sta gåm de ling, der star." - "Ja, der stà on kasse mer 30.000 mark kurt" " "^u gemder har vi mok "f", siger "An, "blacder har vi nok al, siger konen, "bild De vil tillade det," siger han, "så vil jeg blive her nogle dage, og så vil jeg betale for, at fă kassen gravet op, hvis jeg må få en del af pengene." Manden stod ude 1 laden og tærskede, og kone taler så til datteren: "Marie, kald på far, og lad ham komme ind." Så kom han "Hvad synes du om det, den fremmede mand siger? Han vil blive her og grave $i$ vores have på egen regning, hvis han må få en del af de penge, han finder. Må han grave for dig?" - "Ja, såmænd må han det, men det meste vil jeg da have, hvis der er noget. Her er Hans og Peter, de har ikke noget at bestille, så kan de jo få arbejde". De fik så det hele stillet an og kommer til at grave. Da de kom så seks alen ned, siger de: "Nu vil vi ikke grave længere ned, for der er ingen kasse." Men da lod jøden en blank daler glide ned $i$ hånden dem, on da de sà havded $i$ handen a dem, og da de sa havde gravet en halv alen til, sa kom kassen til syne. Nu kan I stole pa, drog kassen op, og den indeholdt alle pengene vet, at der var atter en kasse længere vet, at der var atter en kasse længere nede, og den indeholdt lige så mange og efter to timers arbejde havde de den oppe også. Men så blev regeringen opmærksom på sagen. Den ville have den ene halvdel, og jøden ville havde den anden halvdel. Det kom til en retssag, og den varede i seks år, og det endt med, at der ikke var mere en 4000 gamle mark tilbage til folkene. Så solgte de deres gård og rejste til Jylland.

62 Her er forkortelserne opløste. Den oprindelige version af sagnet $\mathrm{i}$ feltnoterne kan læses Danielsen 2017, s. 269-271 (HAU10).

63 Foster 1965, s. 296-297.

64 Foster 1972, s. 58.

65 DDO, jantelov. Ordet er ifølge DDO dannet i 1933, hvor Aksel Sandemose (1899-1965) formulerede janteloven romanen En flyktning krysser sitt spor, der udkom på dansk i 1938.
66 Lindow 1982.

68 Jf. Lindow 1982, s. 269 med henvisninger.

Schultz Hansen 1994, s. 17-20.

70 Ibid., s. 21-22.

71 Tang Kristensen 1892-1901, 3, 2197; sagnet analyserer jeg Danielsen 2017, s. 185-190, og det kan læses i versionen fra feltnoterne s. 271-273 (HAU11). Haugaards materiale afbrydes midlertidigt i feltnoterne (DFS 1929/16) efter sagnet om jødens skattegravning (HAU10) pà side 6821a og begynder først igen med HAU11 fra side 6824a. Derfor er det usikkert om sagnet HAU11 i realiteten blev fortalt i umiddelbar forlængelse af HAU10 (se nærmere Danielsen 2017, s. 263 og 271). Temaet om skattegravning danner dog en så naturlig kobling melem de to sagn, at det nemt kunne have været tilfældet.

72 Bech 1945, s. 109; samme 1956, s. 4

73 Tang Kristensen 1923-1928, 4, s. 47.

74 Bech 1956, s. 4.

75 Schultz Hansen 2009, s. 187-188.

76 Thomsen 1940, s. 231; jf. nekrologen Haugaard død i Flensborg Avis 18.02.1920 [s. 3]; Bech 1945, s. 110; samme 1956, s. 4.

77 Fra at have tre ansatte i 1860 er Festesens klædefabrik nået op på otte medarbejdere i 1879-1880. Herefter falder antallet af ansatte og kommer aldrig over fire fra 1884 og frem til 1905, hvor fabrikken vistnok er lukket efter at have haft to ansatte året før (Hansen Nielsen 2007, s. 172, tabel 10.21)

78 Worsøe 1974, s. 103-104.

79 Danielsen 2017, s. 185-190. Se note 71 ovenfor.

80 Tang Kristensen 1923-1928, 4, s. 47.

på Den Store Danske: "I vore dage har begrebet sagn fået et præg af usandfærdighed og betegner i daglig tale en beretning fra tidligere tider som man ikke ganske kan fæste lid til" (Jensen 2011). 


\section{Zusammenfassung}

Im vorliegenden Artikel soll aufgezeigt werden, wie sich die Sagen eines Erzählers in Verhältnis zu seiner eigenen Person und seiner Zeit Bedeutung erschaffen. Es sind zwei Sagen, die vom dänischen Volkskundler Evald Tang Kristensen (1843-1929) beim Informanten Christian C. Haugaard (1836-1920) 1894 in Aabenraa in Feldarbeit eingesammelt wurde. Haugaard war der Sohn eines Kötters aus Nørre Hjarup im Kirchspiel Østerløgum. Als junger Mann zieht er nach Aabenraa, wo er eine Lehre als Färber beendete. Haugaard wurde im Nachhinein als sehr dänischgesinnte Persönlichkeit beurteilt und als jemand dargestellt, der der deutschen Obrigkeit trotzte. Diese Seite in ihn wird in einer Sage deutlich, wo er eben die Unterschiede zwischen juridischen und moralischen Gesetzen in der Gesellschaft absucht. Die Sage hat übrigens eine literarische Quelle.

In der zweiten Sage geht es um sein Verhältnis zu dem finanziellen Wachstum einer Gesellschaft; man vernimmt, wie er selbst im ärmeren Teil einer Agrargesellschaft aufgewachsen ist, und wie er versucht diese sozialen Wurzeln zu ändern, was vielleicht nicht ganz gelingt.

\section{Krabbe-affæren}

- et valg for eller imod de danske sønderjyder

Af Klaus Tolstrup Petersen

Op til det danske folketingsvalg i 1901 kom Venstres spidskandidat i Kalundborgkredsen, den tidligere formand for Folketinget Christopher Krabbe, ud $i$ et voldsomt politisk stormvejr. Krabbes datter havde som redaktør af den dansksprogede avis i Sønderjylland Dannevirke ført en tyskvenlig linje, som havde lagt hende for had blandt de dansksindede sønderjyder. Da Krabbe i nogle avisartikler tog hende i forsvar, rejste der sig både nord og syd for grænsen en bevægelse, som indædt forsøgte at hindre hans genvalg til Folketinget. Valgkampen i Kalundborg udviklede sig derfor til et nationalt anliggende, som drejede sig om forholdene syd for den dansk-tyske grænse, og om hvorvidt Krabbe skulle stå til regnskab for datterens gerninger eller ej. Dette forløb og eftervirkningerne heraf undersøges i denne artikel.

\section{Indledning}

Ved Folketingsvalget i 1901 blev Kalundborgkredsen omdrejningspunkt for en usædvanlig valgkamp, hvor forholdene syd for den daværende dansk-tyske grænse fik stor indflydelse på valgets forløb og var tæt på at vælte en af landets mest fremtrædende politikere. Venstres daværende folketingsmedlem i kredsen, den tidligere formand for Folketinget og herredsfoged i Lysgård og Hids Herreder Christopher Krabbe, lignede på forhånd en stensikker spidskandidat for partiet, og hvis det skulle ende med, at Venstre kunne danne regering, var han endda spået gode chancer for en ministerpost. Henover efteråret og vinteren 1900-01 rejste der sig imidlertid en bevægelse af fremtrædende personer fra alle sider af det politiske spektrum, som arbejdede for at hindre Krabbes genvalg og få ham til at trække sig fra politik. Baggrunden for denne bevægelse var at Krabbes datter, Margrethe von Wildenrath-Krabbe, som redaktør af de dansksprogede aviser i Sønderjylland Dannevirke og Det gamle Dannevirke, havde pådraget sig mange danske og dansksindede sønderjyders vrede. De mente, at hun havde redigeret aviserne efter en tyskvenlig linje, og at hun var i ledtog med de tyske myndigheder, som forsøgte at tæmme den dansk nationale bevægelse i Sønderjylland, der arbejdede for at fremme en genforening med Danmark. Flere talte ligefrem om decideret forræderi og det endda i en tid, 